SULUH
JMP
JURAL BIMBINGAN DAN KONSELING
http: //journal. umpalangkaraya. ac. id/index. php/suluh
Volume 4 Nomor 2, Februari 2019 (33-41)

\title{
KONSELING KELOMPOK DENGAN TEKNIK SELF MANAGEMENT UNTUK MENURUNKAN PRASANGKA SOSIAL PESERTA DIDIK
}

\section{Counseling Group With Self Management Techniques To Reduce Social Prejudice Learners}

\author{
'Esty Ariyani Safithry, ${ }^{2}$ Niky Anita \\ 'Universitas Muhammadiyah palangkaraya, Palangka Raya, Kalimantan Tengah, Indonesia \\ ${ }^{2}$ Universitas Muhammadiyah palangkaraya, Palangka Raya, Kalimantan Tengah, Indonesia
}

\begin{abstract}
ARTIKEL INFO
ABSTRAK

Diterima

Januari 2019

Dipublikasi

Februari 2019

Penelitian ini bertujuan untuk mengetahui layanan konseling kelompok dengan teknik self management dalam menurunkan prasangka social peserta didik. Jenis penelitian yang digunakan adalah kuantitatif dengan teknik Pre-Eksperiment dangn bentuk OneGroup Pretest-Posttest Design. Populasi dalam penelitian ini adalah peserta didik kelas X mipa-7 di SMAN 2 Palangka Raya yang berjumlah 40 orang, dengan sampel 9 orang peserta didik yang teridentifikasi memiliki tingkat prasangka social yang tinggi. Data di analisis dengan uji T Test Menggunakan aplikasi Software SPSS versi 20.00 . teknik pengumpulan data menggunakan, observasi dan skala prasangka sosial. Berdasarkan hasil Pre-test sebelum pemberian treatment subjek mendapatkan nilai skor rata-rata 86-I I4 masuk dalam kategori tinggi, dan setelah pemberian treatmen berdasarkan hasil Post-test rata-rata subjek mendapatkan nilai skor 57-85 dan masuk dalam kategori sedang. Pada observasi awal sebelum pemberian treatment mendapatkan nilai skor 9-13 masuk dalam kategori rendah dan setelah pemberian treatment pada observasi akhir rata-rata subjek mendapatkan nilai skor 4-8 masuk dalam kategori rendah. Hasil penelitian menunjukan kesembilan peserta didik yang diberikan treatment mengalami penurunan perilaku prasangka sosial sesudah pemberian treatment yang diketahui dari hasil perbandingan Pretest-Posttest.
\end{abstract}

*E-mail:

estyaryanisafithry@gmail. com

Orchid:
Kata kunci: Konseling Kelompok, Self Management, Prasangka Sosial

\section{ABSTRACT}

This study aims to determine group counseling services with self management techniques in reducing the social prejudices of students. The type of research used is quantitative with Pre-Experiment technique and the form of One-Group Pretest-Posttest Design. The population in this study were students of class $X$ mipa-7 at SMAN 2 Palangka Raya, amounting to 40 people, with a sample of 9 students identified as having a high level of social prejudice. The data is analyzed with the T Test using the SPSS software version 20.00. data collection techniques using, observation and social prejudice scale. Based on the results of the Pre-test before administering the treatment the subjects got an average score score of 86-1 / 4 in the high category, and after giving treatment based on the results the average post-test subjects got a score of 57-85 and were in the medium category. In the initial observation before giving treatment, the score of 9-13 was included in the low category and after giving treatment on the final observation, the average subject scored 4-8 in the low category. The results showed that the nine students given treatment experienced a decrease in social prejudice behavior after treatment which was known from the results of the Pretest-Posttest comparison.

Keywords: Group Counseling, Self Management, Social Prejudice 
Jurnal Bimbingan dan Konseling

\section{PENDAHULUAN}

Sekolah adalah dimana tempat kita dalam menuntut ilmu, menerima pelajaran, tempat bersosialisasi, tempat berinteraksi, dan juga sekolah adalah tempat untuk mencari teman. Dalam lingkungan sekolah cukup banyak kita jumpai peserta didik yang berasal dari berbagai wilayah, daerah, suku, status sosial dan agama yang berbeda-beda. Sekolah mengajarkan peserta didik untuk saling menyayangi dan menghormati terhadap guru, orang tua, dan sesama teman.

Peserta didik adalah orang yang sedang berada pada fase pertumbuhan dan perkembangan baik secara fisik maupun pisikis, pertumbuhan dan perkembangan merupakan ciri dari seseorang peserta didik yang perlu bimbingan dari seorang pendidik. Sedangkan prasangka adalah suatu sikap yang tidak toleraan, tidak fair, atau tidak favourable terhadap sekelompok orang. Prasangka menurut pendapat Sherif dan Sherif (dalam Sobur, 20I3) mengungkapkan bahwa prasangka adalah suatu istilah yang menunjuk pada sikap yang tidak menyenangkan yang dimiliki oleh anggota-anggota suatu kelompok terhadap kelompok lain berikut anggotaanggotanya yang didasarkan atas normanorma yang mengatur perlakuan terhadap orang-orang di luar kelompoknya.

Prasangka sosial menurut Manstead dan Hewstone (dalam Fitria 2013) mendefinisikan sebagai suatu keadaan yang berkaitan dengan sikap-sikap dan keyakinan-keyakinan yaitu ekspresi perasaan negatif, penunjukkan sikap bermusuhan atau perilaku diskriminatif terhadap anggota kelompok lain. Faktor penyebab timbulnya prasangka sosial antar lain: Menurut pendapat Ahmadi (2007:194) menjelaskan bahwa faktor penyebab timbulnya prasangka ada 5 diantaranya:

a) Orang berprasangka dalam rangka mencari kambing hitam.

b) Orang berprasangka karena memang ia sudah dipersiapkan didalam liangkungannya atau kelompoknya untuk berprasangka. c) Prasangka timbul karena adanya perbedaan, di mana perbedaan ini menimbulkan perasaan superior. Misalnya, perbedaan fisik, agama, kekayaan, norma sosial dan lain sebagainya.

d) Prasangka timbul karena kesan yang menyakitkan atau pengalaman yang tidak menyenangkan.

e) Prasangka timbul karena adanya anggapan yang sudah menjadi pendapat umum atau kebiasaan di dalam lingkungan tertentu.

Menurut pendapat Rose (dalam Gerungan) mengatakan bahwa dampak prasangka sosial dapat merugikan masyarakat secara umum dan organisasi khususnya. Hal ini terjadi karena prasangka sosial dapat menghambat perkembangan potensi individu secara maksimal. Muncul prasangka dikalangan peserta didik karena peserta didik itu sendiri mengasumsikan pemikiraan-pemikirannya dengan hanya menilai sekilas, sehingga lamakelamaan asumsi itu dapat berubah menjadi fitnah dan akhirnya menjadi permusuhan. Melihat kondisi diatas maka perlu ditangani masalah tersebut oleh guru BK, guru BK dapat menggunakan berupa Layanan Konseling Kelompok. Menurut pendapat sukardi (2008:68) mengemukakan bahwa pelayanan konseling kelompok yaitu layanan bimbingan dan konseling yang memungkinkan peserta didik memperoleh kesempatan untuk pembahasan dan pengentasan permasalahan yang dialaminya melalui dinamika kelompok.

Sedangkan menurut pendapat Supriatna (20I4:107) berpendapat bahwa konseling kelompok adalah suatu upaya bantuan kepada peserta didik dalam suasana kelompok yang bersifat pencegahan dan pemyembuhan, dan diarahkan kepada pemberian kemudahan dalam rangka perkembangan dan pertumbuhannya.

Penjelasan diatas dapat disimpulkan konseling kelompok merupakan suatu upaya pemberian bantuan yang diberikan kepada peserta didik dalam suasana kelompok yang besifat pencegahan dan penyembuhan.

Tujuan yang ingin dicapai dari layanan konseling kelompok antara lain: Menurut 
Jurnal Bimbingan dan Konseling

Mungin Eddy Wibowo, (dalam Sucipto 2016). Tujuan yang ingin dicapai dalam konseling kelompok, yaitu pengembangan pribadi, pembahasan dan pemecahan masalah pribadi yang dialami oleh masingmasing anggota kelompok, agar terhindar dari masalah dan masalah terselesaikan dengan cepat melalui bantuan anggota kelompok yang lain.

Menurut Raharjo (dalam Indriasari 2016:194) tahap konseling kelompok dibagi menjadi 4 tahap, yaitu :

a) Tahap pembentukan, pembentukan kelompok merupakan tahap awal yang sangat berpengaruh dalam proses konseling kelompom selanjutnya.

b) Tahap peralihan, adalah terbebaskannya anggota dari perasaan atau sikap enggan, ragu, malu, atau saling tidak percaya untuk memasuki tahap berikutnya, makin mantapnya suasana kelompok dan kebersamaan, makin mantapnya minat untuk ikut serta dalam kegiatan kelompok.

c) Tahap kegiatan, bertujuan membahas suatu masalahnya atau topik yang relevan dengan kehidupan anggota secara mendalam dan tuntas.

d) Tahap penutup, merupakan penilaian dan tindak lanjut, adanya tujuan terungkapnya kesan-kesan anggota kelompok tentang pelaksanaan kegiatan, terungkapnya hasil kegiatan kelompok yang telah dicapai yang dikemukakan secara mendalam dan tuntas, terumuskan rencana kegiatan lebih lanjut, tetap dirasakannya hubungan kelompok dan rasa kebersamaan meskipun kegiatan diakhiri.

Menurut pendapat Munro, Manthei, dan Small (dalam Folastri dan Rangka 2016:30) menjelaskan bahwa asas-asas yang terdapat dalam layanan konseling kelompok ada 6 diantaranya:

a) Asas kerahasiaan
Segala sesuatu yang dibahas dan muncul dalam kegiatan kelompok hendaknya menjadi "rahasia kelompok" yang hanya boleh diketahui oleh anggota kelompok dan tidak disebarluaskan ke luar kelompok. Seluruh anggota kelompok hendaknya menyadari benar hal ini dan bertekad dengan sungguh-sungguh untuk melaksanakannya.

b) Asas kesukarelaan

Kesukarelaan terus-menerus dibina melalui upaya konselor/pemimpin kelompok dalam mengembangkan syarat-syarat kelompok yang efektif dan penstrukturan tentang layanan bimbingan kelompok maupun konseling kelompok. Dengan kesukarelaan itu anggota kelompok akan dapat mewujudkan peran aktif diri mereka masing-masing untuk mencapai tujuan layanan.

c) Asas kegitan

Dinamika kelompok dalam kegiatan bimbingan kelompok dan konseling kelompok semakin intensif dan efektif apabila semua anggota kelompok secara penuh menerapkan asas kegiatan.

d) Asas keterbukaan

Mereka secara aktif dan terbuka menampilkan diri tanpa rasa takut, malu ataupun ragu.

e) Asas kekinian

Asas kekinian memberikan isi aktual dalam pembahasan yang dilakukan, anggota kelompok diminta mengemukakan hal-hal yang terjadi dan berlaku sekarang ini. Halhal atau pengalaman yang telah lalu dianalisis dan disangkut pautkan untuk kepentingan pembahasan hal-hal yang terjadi dan berlaku sekarang. Hal-hal yang akan datang direncanakan sesuai dengan kondisi yang ada sekarang.

f) Asas kenormatifan

Asas kenormatifan dipraktikkan berkenaan dengan cara-cara berkomunikasi dan 
Jurnal Bimbingan dan Konseling

bertatakrama dalam kegiatan kelompok, serta dalam mengemas isi bahasan

Komponen yang dimiliki layanan konseling kelompok antara lain:

\section{Pemimpin Kelompok}

Menurut pendapat Prayitno (2004:4) menjelaskan bahwa pemimpin kelompok adalah seorang konselor yang terlatih dan memiliki keterampilan serta kemampuan memimpin suatu kelompok konseling untuk mencapai tujuan kelompok. Konselor sebagai pemimpin kelompok bertanggung jawab penuh terhadap kelompok.

2. Anggota Kelompok

Menurut pendapat Hadi (2016:102) mengungkapkan bahwa anggota kelompok, merupakan sekumpulan orang yang secara sukarela mengikuti kegiatan kelompok dengan dipimpin oleh seorang konselor atau guru bimbingan konseling yang profesional serta memiliki tujuan yang sama antar anggota kelompok.

3. Dinamika Kelompok

Menurut pendapat Folastri dan Rangka (2016:II) mengungkapkan bahwa Dinamika kelompok merupakan sinergi dari semua faktor yang ada di dalam suatu kelompok; artinya merupakan pengerahan secara serentak semua faktor yang dapat digerakkan dalam kelompok itu. Dengan demikian, dinamika kelompok merupakan jiwa yang menghidupkan dan menghidupi suatu kelompok.

Layanan konseling kelompok memiliki kelebihan dan juga kelemahan diantaranya:

Kelebihan dari layanan konseling kelompok menrut pendapat Lubis dan Hasnida (2016:203) adalah dengan melalui kelompok bantuan diri, individu-individu mengembangkan dan meningkatkan kepercayaan diri dan identitas diri mereka. Mereka menyadari bahwa tidak sendirian, dan merasa lebih diberdayakan melalui pertukaran gagasan serta memberikan bantuan, sebagaimana halnya menerima bantuan itu sendiri.
Menurut pendapat Natawidjaja (dalam Astuti 2012:9) mengungkapkan bahwa kelemahan yang ada pada konseling kelompok ada 5 diantaranya:

a) Tidak semua orang cocok dalam kelompok,

b) Perhatian konselor lebih menyebar atau meluas,

c) Mengalami kesulitan dalam membina kepercayaan,

d) Konseli mengharapkan terlalu banyak tuntutan dari kelompok,

Kelompok bukan dijadikan sebagai sarana berlatih untuk melakukan perubahan namun sebagai tujuan. Tujuan diberikannya layanan Konseling Kelompok diharapkan para peserta didik dapat mengurangi sikap prasangkanya terhadap peserta didik lainnya. Layanan konseliling kelompok itu sendiri menurut pendapat Winkel (dalam Lubis 20II:198) merupakan pelaksanaan proses konseling yang dilakukan antara seorang konselor profesional dan beberapa klien sekaligus dalam kelompok kecil. Dengan tujuan untuk proses belajar dan upaya untuk membantu klien dalam pemecahan masalahnya.

Pada pelaksanaan layanan bimbingan kelompok terdapat berbagai teknik salah satunya adalah menggunakan teknik self management. Menurut pendapat Cormier (dalam Alamri 2015) self management atau pengelolaan diri adalah suatu strategi pengubahan perilaku yang dalam prosesnya konseli mengarahkan perubahan perilakunya sendiri dengan suatu teknik atau kombinasi teknik teurapetik. Alasan saya menggunakan teknik self management ini adalah teknik ini sangat cocok digunakan untuk masalahmasalah peserta didik dengan perilaku yang tidak berkaitan dengan orang lain tetapi mengganggu orang lain dan diri sendiri seperti perilaku prasangka, sehingga dengan menggunakan teknik ini konselor dapat mengubah atau mengurangi perlaku prasangka pada peserta didik. Berdasarkan paparan sebelumnya bahwa dampak prasangka yang dialami peserta didik maka peneliti ingin 
Jurnal Bimbingan dan Konseling

melaksanakan layanan konseling kelompok dengan teknik self management. Menurut pendapat Komalasari dan Wahyuni (20II:180) menjelaskan bahwa pengelolaan diri (self management) adalah prosedur dimana individu mengatur perilakunya sendiri.

Yates (dalam Mulyadi,dkk 2017:49) mengemukakan bahwa manajemen diri adalah suatu proses yang dilakukan oleh individu dalam mengarahkan perilakunya dengan menggunakan suatu siasat atau kombinasi siasat terapi agar mampu berpeirlaku positif dan produktif. Manajemen diri itu merupakan salah satu cara yang lazim digunakan dalam tradisi bimbingan dan konseling. Penggunaannya dapat dikenakan kepada berbagai sasaran perilaku.

Penjelasan diatas dapat disimpulkan bahwa self management merupakan suatu prosedur dimana klien diberikan kesempatan dalam mengarahkan perilaku atau mengatur perubahan tingkah lakunya sendiri ataupun dengan menggunakan strategi.

Menurut pendapat Komalasari dan Wahyuni (20II:I82) mengungkapkan bahwa tahapan self management ada 3 diantaranya:

a) Tahap monitor diri atau observasi diri

Pada tahap ini konseli dengan sengaja mengamati tingkah lakunya sendiri serta mencatatnya dengan teliti.

b) Tahap evalusi diri

Pada tahap ini konseli membandingkan hasil catatan tingkah laku dengan target tingkah laku yang telah dibuat oleh konseli.

c) Tahap pemberian penguatan, penghapusan atau hukuman

Pada tahap ini konseli mengatur dirinya sendiri, memberikan penguatan, menghapus dan memberikan hukuman pada diri sendiri.

Menurut Cormier (dalam Zubaedah 20I7:73) mengemukakan bahwa macammacam tahapan self management ada 3 yaitu:

a) Self-Monitoring (pemantauan diri), SelfMonitoring adalah suatu proses dimana klien mengamati dan mencatat hal-hal tentang diri mereka dan interaksi mereka dengan situasi lingkungan.

b) Stimulus control yaitu dapat digunakan untuk mengurangi perilaku-perilaku yang tidak diinginkan dan meningkatkan perilaku-perilaku yang diinginkan.

c) Self-reward digunakan pada sasaran perilaku penguat ketika pelaksanaannya diikuti oleh respon yang ditargetkan.

Penjelasan diatas dapat ditarik kesimpulan bahwa terdapat 3 tahapan teknik self management yaitu tahap monitoring, tahap evaluasi diri dan tahap pemberian penguatan, dimana tahap monitoring adalah tahap mengamati atau mengobservasi tingkah lakunya, kedua tahap evalusi adalah tahap dimana konseli membandingkan catatan tingkah laku dengan target tingkah laku yang telah dibuat, dan yang terakhir tahap pemberiaan penguatan adalah tahap dimana digunakan untuk membantu klien mengatur dan memperkuat perilakunya melalui konsekuensi yang dihasilkannya sendiri.

Menurut pendapat Mulyadi,dkk (2017:49) mengungkapkan bahwa Keunggulan manajemen diri ada 4 diantaranya:

a) Pelaksanaannya yang cukup sederhana.

b) penerapannya dikombinasikan dengan beberapa pelatihan yang lain.

c) Pelatihan ini dapat mengubah perilaku individu secara langsung melalui perasaan dan sikapnya.

Dapat dilaksanakan secara perorangan juga dapat dilaksanakan dalam kelompok. Alternatif penyelesaian masalah prasangka sosial yang dialami peserta didik yang peneliti laksanakan bukan solusi total namun hanya sebagai solusi awal. Peneliti akan melaksanakan penelitian dengan judul "Konseling kelompok dengan Teknik Self Management untuk Menurunkan Prasangka Sosial Peserta didik

\section{METODE PENELITIAN}

Metode penelitian yang digunakan dalam penelitan ini adalah metode preeksperimen. Menurut Creswell (2010:24I) 
rancangan penelitian mencangkup satu kelompok yang diobservasi pada tahap pretest. Menurut pendapat Sugiyono (2016:72) menjelaskan bahwa penelitian ekperimen adalah metode penelitian yang digunakan untuk mencari pengaruh perlakuan tertentu terhadap yang lain dalam kondisi yang terkendali. Design penelitian merupakan rancangan bagaimana penelitian dilaksanakan. Design penelitian yang digunakan dalam penelitian ini adalah one grup pre-test. Dalam desain ini, sebelum perlakuan diberikan dahulu sampel diberi pre-test (tes awal) setelah itu diberikan treatment (perlakuan) dan di akhir pembelajaran sampel diberi posttest(tes akhir).

Penelitian ini dilakukan di SMAN-2 Palangka Raya. Populasi dalam penelitian ini adalah kelas X MIPA 7 di SMAN 2 Palangka Raya dengan 9 orang sampel peserta didik.

Menurut Sugiyono

(2014:178)

mengemukakan bahwa instrumen penelitian adalah alat yang digunakan dalam mengukur fenomena alam maupun sosial yang diamati, atau sering dikenal dengan variabel penelitian. Instrumen yang digunakan dalam penelitian ini terdiri dari bahan perlakuan berupa skla prasangka dan rubrik observasi, sebelum instrumen itu digunakan dalam penelitian terlebih dahulu dilakukan uji validitas konstruksi ( validitas ahli).

Langkah selanjutnya, penghitungan validitas dan realiabilitas dengan menggunakan program software SPSS (statistic package the sosial sciences). Versi 20, dari hasil penghitung tersebut kemudian dapat diketahui dari 80 item jumlah pernyataan didapatkan 52 item yang tidak valid dan 28 item yang valid.

Table I. Hasil Reliabilitas

\begin{tabular}{|l|l|}
\hline Cronbach's Alpha & N of Items \\
\hline .674 & 28 \\
\hline \multicolumn{2}{|c|}{ Uji reliabilitas dihitung dan dianalisis }
\end{tabular}
dengan program SPSS (Statistical Package for Social Science) Hasil uji reliabilitas dari sakla yang digunakan dalam penelitian ini menunjukan hasil bahwa nilai cronbach's alpha yang didapat adalah 0,674. Berdasarkan hasil dari pengambilan keputusan yang telah disebutkan diatas, maka diperoleh kesimpulan nilai $t$ hitung $>t$ table yaitu dengan nilai skor $0,674>0,220$ maka skala yang digunakan dalam penelitian ini dinyatakan reliable.

Menurut Sugiyono (2013:169) analisis data merupakan kegiatan setelah data dari seluruh responden atau sumber data lain terkumpul.

Dalam menentukan efektifitas tidaknya pelaksanaan layanan konseling kelompok dengan teknik self managemet ini analisi data yang digunakan adalah perbandingan hasil skor rata-rata pre-test dan post-test dari objek penelitian. Analisis data menggunakan analisis data statistik dekriptif untuk mendeskripsikan atau menggambarkan data yang telah terkumpul pada sampel, untuk mengetahui keefektifan atau hasil perbandingan menggunakan analisis uji $\mathrm{T}$ menggunakan aplikasi software program SPSS20.

\section{HASIL DAN PEMBAHASAN}

\section{Gambaran Hasil Konseling Kelompok Dengan Teknik Self Management}

Waktu penelitian dilaksanakan pada bulan Maret sampai Mei 2018. Selanjutnya peneliti menetapkan subjek penelitian dengan melakukan penyebaran skala prasangka sosial. Prasangka sosial peserta didik dikategorikan menjadi 3 yaitu: tinggi, sedang, dan rendah.

Hasil pemberian skala prasangka sosial peserta didik kelas X IPA 7 teridentifikasi sembilan siswa yang memiliki prasangka sosial yang cukup tinggi berdasarkan kriteria di atas.

Table 2. Hasil Pre-Test

\begin{tabular}{|l|l|l|}
\hline $\begin{array}{l}\text { Peserta } \\
\text { Didik }\end{array}$ & $\begin{array}{l}\text { Skor Pre- } \\
\text { test }\end{array}$ & Kategori \\
\hline KSW & 81 & SEDANG \\
\hline MD & 90 & TINGGI \\
\hline SK & 85 & SEDANG \\
\hline A & 89 & TINGGI \\
\hline FAIS & 94 & TINGGI \\
\hline DKR & 83 & SEDANG \\
\hline RN & 89 & TINGGI \\
\hline DMP & 84 & SEDANG \\
\hline
\end{tabular}


Jurnal Bimbingan dan Konseling

\begin{tabular}{|l|l|l|}
\hline MR & I02 & TINGGI \\
\hline
\end{tabular}

\begin{tabular}{|l|l|l|}
\hline $\begin{array}{l}\text { Peserta } \\
\text { Didik }\end{array}$ & $\begin{array}{l}\text { Skor } \\
\text { Post-test }\end{array}$ & Kategori \\
\hline KSW & 56 & RENDAH \\
\hline MD & 84 & SEDANG \\
\hline SK & 71 & SEDANG \\
\hline A & 80 & SEDANG \\
\hline FAIS & 83 & SEDANG \\
\hline DKR & 72 & SEDANG \\
\hline RN & 80 & SEDANG \\
\hline DMP & 63 & SEDANG \\
\hline MR & 84 & SEDANG \\
\hline
\end{tabular}

Tabel 4 Hasil Observasi Awal Prasangka Sosial Peserta didik

\begin{tabular}{|l|l|l|}
\hline $\begin{array}{l}\text { Peserta } \\
\text { Didik }\end{array}$ & $\begin{array}{l}\text { Skor } \\
\text { Observasi }\end{array}$ & Kategori \\
\hline KSW & 10 & SEDANG \\
\hline MD & 12 & SEDANG \\
\hline SK & $1 \mathrm{I}$ & SEDANG \\
\hline A & 10 & SEDANG \\
\hline FAIS & 16 & TINGGI \\
\hline DKR & 11 & SEDANG \\
\hline RN & 11 & SEDANG \\
\hline DMP & 13 & SEDANG \\
\hline MR & 16 & TINGGI \\
\hline
\end{tabular}

Table 5. Hasil Observasi Akhir Prasangka Sosial Peserta didik

\begin{tabular}{|l|l|l|}
\hline $\begin{array}{l}\text { Peserta } \\
\text { Didik }\end{array}$ & $\begin{array}{l}\text { Skor } \\
\text { Observasi }\end{array}$ & Kategori \\
\hline KSW & 9 & SEDANG \\
\hline MD & 8 & RENDAH \\
\hline SK & 9 & SEDANG \\
\hline A & 8 & RENDAH \\
\hline FAIS & 10 & SEDANG \\
\hline DKR & 8 & RENDAH \\
\hline RN & 6 & RENDAH \\
\hline DMP & 8 & RENDAH \\
\hline MR & $6 \quad$ & TINGGI \\
Data Subjek Penelitian Dalam \\
Mengikuti Kegiatan Konseling
\end{tabular}

Peserta didik MR saat pre-test awal mendapatkan skor 102 masuk dalam kategori tinggi dan observasi awal mendapatkan nilai skor 16 dan termasuk dalam kategori tinggi, tetapi pada saat observasi akhir peserta didik MR mendapatkan nilai skor 6 dan masuk kedalam kategori rendah dan setelah pemberian treatment pada post-test akhir mendapatkan jumlah skor 84 masuk dalam kategori sedang. Sehingga dapat dilihat bahwa peserta didik MR mengalami perubahan penurunan tingkat prasangka sosial yang sangat signifikan setelah pemberian treatment. Setelah mengikuti layanan koneling kelompok dengan teknik self management peserta didik MR sadar bahwa prasangka buruk adalah perilaku yang tidak baik dan harus diubah sehingga MR berusaha untuk mengurangi dan menghilangkan prasangka buruk kepada orang lain.

Peserta didik DMP saat pre-test awal mendapatkan skor 84 msuk dalam kategori sedang dan observasi awal mendapatkan nilai skor 13 dan termasuk dalam kategori sedang, tetapi pada saat observasi akhir peserta didik DMP mendapatkan nilai skor 8 dan masuk kedalam kategori rendah dan setelah pemberian treatment pada post-test akhir mendapatkan jumlah skor 63 masuk dalam kategori sedang. Sehingga dapat dilihat bahwa peserta didik DMP mengalami perubahan penurunan tingkat prasangka sosial yang sangat signifikan setelah pemberian treatment. Setelah mengikuti layanan koneling kelompok dengan teknik self management peserta didik DMP beruhasa untuk lebih memiliki prasangka baik dari pada prasangka buruk.

Peserta didik RN saat pre-test awal mendapatkan skor 89 masuk dalam kategori tinggi dan observasi awal mendapatkan nilai skor II dan termasuk dalam kategori sedang, tetapi pada saat observasi akhir peserta didik RN mendapatkan nilai skor 6 dan masuk kedalam kategori rendah dan setelah pemberian treatment pada post-test akhir mendapatkan jumlah skor 80 masuk dalam kategori sedang. Sehingga dapat dilihat bahwa peserta didik $\mathrm{RN}$ mengalami perubahan penurunan tingkat prasangka sosial yang sangat signifikan setelah pemberian treatment. Setelah mengikuti layanan koneling kelompok dengan teknik self management peserta didik 
Jurnal Bimbingan dan Konseling

RN mengetahui konsekuensi apa yang akan didapatnya jika berprasangka buruk kepada orang lain sehingga peserta didik RN tidak akan cepat dalam mengambil keputusan sebelum mengetahui kebenarannya.

Peserta didik DKR saat pre-test awal mendapatkan skor 83 masuk dalam kategori sedangobservasi awal mendapatkan nilai skor II dan termasuk dalam kategori sedang, tetapi pada saat observasi akhir peserta didik DKR mendapatkan nilai skor 8 dan masuk kedalam kategori rendah dan setelah pemberian treatment pada post-test akhir mendapatkan jumlah skor 72 masuk dalam kategori sedang. Sehingga dapat dilihat bahwa peserta didik DKR mengalami perubahan penurunan tingkat prasangka sosial yang cukup signifikan setelah pemberian treatment. Setelah mengikuti layanan koneling kelompok dengan teknik self management peserta didik DKR akan berusaha untuk berprasangka baik kepada orang lain dan mengurangi prasangka buruknya.

Peserta didik FAIS saat pre-test awal mendapatkan skor 94 masuk dalam kategori tinggi dan observasi awal mendapatkan nilai skor 16 dan termasuk dalam kategori tinggi, tetapi pada saat observasi akhir peserta didik FAIS mendapatkan nilai skor 10 dan masuk kedalam kategori sedang dan setelah pemberian treatment pada post-test akhir mendapatkan jumlah skor 83 masuk dalam ktegori sedang. Sehingga dapat dilihat bahwa peserta didik FAIS mengalami perubahan penurunan tingkat prasangka sosial yang cukup signifikan setelah pemberian treatment. Setelah mengikuti layanan koneling kelompok dengan teknik self management peserta didik FAIS sadar bahwa tidak boleh berprasangka buruk ataupun menuduh orang lain negatif tanpa mengetahui faknya terlebih dahulu jadi peserta didik FAIS akan mencari kebenaran dan fakta mengenai sesuatu sebelum dia berprasangka.

Peserta didik A saat pre-test awal mendapatkan skor 89 masuk dalam kategori tinggi dan observasi awal mendapatkan nilai skor 10 dan termasuk dalam kategori sedang, tetapi pada saat observasi akhir peserta didik A mendapatkan nilai skor 6 dan masuk kedalam kategori rendah dan setelah pemberian treatment pada post-test akhir mendapatkan jumlah skor 80 masuk dalam kategori sedang. Sehingga dapat dilihat bahwa peserta didik A mengalami perubahan penurunan tingkat prasangka sosial yang cukup signifikan setelah pemberian treatment. Setelah peserta didik A mengetahui konsekuensi apa yang akan didapat jika berprasangka buruk maka peserta didik SK akan selalu berusaha untuk lebih berprasangka baik kepada orang lain khususnya kepada teman-teman yang ada dilingkungan sekolahnya.

Peserta didik SK saat pre-test awal mendapatkan skor 85 masuk dalam kategori sedang dan observasi awal mendapatkan nilai skor II dan termasuk dalam kategori sedang, tetapi pada saat observasi akhir peserta didik SK mendapatkan nilai skor 9 dan masuk kedalam kategori sedang dan setelah pemberian treatment pada post-test akhir mendapatkan jumlah skor7l masuk dalam kategori sedang. Sehingga dapat dilihat bahwa peserta didik SK mengalami perubahan penurunan tingkat prasangka sosial setelah pemberian treatment. Setelah mengikuti layanan koneling kelompok dengan teknik self management peserta didik SK mengetahui konsekuensi yang didapat jika berpikir negatif kepada orang lain maka SK akan selalu berpikir positif dan mengurangi pikiran negatif kepada orang lain.

Peserta didik MD saat pre-test awal mendapatkan skor 90 masuk dalam kategori tinggi dan observasi awal mendapatkan nilai skor 12 dan termasuk dalam kategori sedang, tetapi pada saat observasi akhir peserta didik MD mendapatkan nilai skor 8 dan masuk kedalam kategori rendah dan setelah pemberian treatment pada post-test akhir mendapatkan jumlah skor 84 masuk dalam kategori sedang. Sehingga dapat dilihat bahwa peserta didik MD mengalami perubahan penurunan tingkat prasangka sosial yang cukup signifikan setelah pemberian treatment. 
Jurnal Bimbingan dan Konseling

Setelah mengikuti layanan koneling kelompok dengan teknik self management peserta didik MD akan selalu berusaha lebih baik lagi untuk mengontrol prasangka buruk yang dimilikinya.

Peserta didik KSY saat pre-test awal mendapatkan skor $8 \mathrm{I}$ masuk dalam kategori sedang dan observasi awal mendapatkan nilai skor 9 dan termasuk dalam kategori sedang, tetapi pada saat observasi akhir peserta didik KSY mendapatkan nilai skor 10 dan masuk kedalam kategori sedang dan setelah pemberian treatment pada post-test akhir mendapatkan jumlah skor 56 dan masuk dalam kategori rendah. Sehingga dapat dilihat bahwa peserta didik KSY mengalami perubahan penurunan tingkat prasangka sosial setelah pemberian treatment. Setelah mengikuti layanan konseling kelompok dengan teknik self management ini peserta didik KSY sadar bahwa dia tidak akan terlalu cepat menilai orang lain karena belum tentu apa yang dilakukan orang lain itu salah dan apa yang kita lakukan adalah benar.

\section{KESIMPULAN}

Berdasarkan hasil analisis dan pembahasan di atas, maka dapat disimpulkan bahwa layanan konseling kelompok dengan teknik self management dapat menurunkan tingkat prasangka sosial peserta didik di kelas $X$ MIPA-7 SMAN 2 Palangka Raya. Hal tersebut didasarkan pada hasil skala Post-test dan Observai menunjukkan bahwa tingkat prasangka sosial peserta didik mengalami penurun. Berdasarkan hasil Pre-test sebelum pemberian treatment subjek mendapatkan nilai skor rata-rata 86-II4 masuk dalam kategori tinggi, dan setelah pemberian treatmen berdasarkan hasil Post-test rata-rata subjek mendaptkan nilai skor 57-85 dan masuk dalam kategori sedang. Sedangkan berdasarkan hasil observasi rata-rata subjek pada observasi awal sebelum pemberian treatment mendapatkan nilai skor 9-13 masuk dalam kategori rendah dan setelah pemberian treatment pada observasi akhir rata-rata subjek mendapatkan nilai skor 4-8 masuk dalam kategori rendah. Hasil analisis ini menunjukan bahwa kesembilan peserta didik pada subjek penelitian mengalami penurunan tingkat prasangka sosial sesudah diberikan perlakuan (treatment).

\section{DAFTAR PUSTAKA}

Abu Ahmadi. 2007. Psikologi Sosial. Jakarta: PT Rineka Cipta

Dewa ketut sukardi. 2008. Pengantar Pelaksanaan Program Bimbingan dan Konseling disekolah. Jakarta: Rineka Cipta

Fattah Hanurawan. 2010. Psikologi Sosial Suati Pengantar. Bandung: PT Remaja Rosdakarya

http://m.detik.com/news/berita/2364888/maha siswa-prasangka-pemicu-konflik-dalammasyarakat-multikultural

Muliyadi, M. Yasda dan Fitriyanti Sulaiman. 2017. Penerapan Teknik Manajemen Diri Dapat Mengurangi Kebiasaan Prokrastinasi Akademik Mahasiswa Stkip Muhammadiyah Enrekang. Volume 3 No

Sisca Folastri dan Itsar Bolo Rangka. 2016. Prosedur Layanan Bimbingan dan Konseling Kelompok. Bandung: Mujahid Press

Sudarwan Danim. 2013. Perkembangan Peserta Didik. Bandung: Alfabeta

Sugiyono. 2016. Metode Penelitian Kuantitatif, Kualitatif, dan R\&G. Bandung : Alfabeta 